\title{
Private Labels and Retail: A Bibliometric Study on Empirical Researches
}

\author{
Marcelo Henrique Espíndola Sandes ${ }^{1}$, Rafael Araújo Sousa Farias ${ }^{1}$ \& José Aurenir Souza dos Santos ${ }^{1}$ \\ ${ }^{1}$ Department of Administrative Sciences, University of Brasília, Brasília, Brazil \\ Correspondence: Rafael Araújo Sousa Farias, Universidade de Brasília, Campus Universitário Darcy Ribeiro, Prédio \\ da FACE, Programa de Pós-Graduação em Administração. CEP: 70910-900, Brasília-DF, Brazil. E-mail: \\ farias-rafael@hotmail.com
}

Received: August 8, 2016

Accepted: September 6, 2016

Online Published: September 20, 2016

doi:10.5430/ijba.v7n5p78

URL: http://dx.doi.org/10.5430/ijba.v7n5p78

\begin{abstract}
This work aims at identifying the characteristics of empirical papers on the issues of private labels and retail, published in national (Brazil) and international journals. The present research is a qualitative descriptive study, which applies a bibliometric analysis, focusing on the works that contribute to the debate on the subjects of private labels and retail, within the scope of marketing. The method to identify scientific works used in this research was the Knowledge Development Process - Constructivist (ProKnow-C). In all, 47 articles were analyzed, 20 national and 27 international. The analyses indicate that papers published in national journals arise mostly from researches conducted in Brazil, Spain is the country in which a higher number of researches on the topic were carried out, the International Journal of Retail \& Distribution Management and the Journal of Product \& Brand Management have shown the greatest number of published works, Cristina Calvo-Porral is the leading international author (4 papers) and Éderson Luiz Piato is the national leading expert (3 publications). The main sub-topics explored in national works differ from their international conterparts, as well as in the methodological structures used to construct the investigation process. International researches are predominantly quantitative pre-experimental, using questionnaires and document analyses, while national are mostly exploratory, descriptive, using questionnaires and interviews.
\end{abstract}

Keywords: bibliometry, marketing, private label, retail

\section{Introduction}

Private label products are those developed and managed by the same company that sells to a final consumer, under its own name or property mark (Dunne \& Lusch, 1999). It is the mark by which the trader assumes responsibility for all the management process - including development, supply, storage, marketing and promotion (Dhar \& Hoch, 1997). While strategies for private label development existed for over a hundred years, their application in a comprehensive manner can be considered a recent phenomenon (Hoch \& Banerji, 1993; Kumar \& Steenkamp, 2007).

An increased consumption of private label products occurred when traders started to add value to their own brands and consumers noticed the value of products (Batra \& Sinha, 2000). Thus, they accepted the idea that traders could develop quality exclusive brands and not necessarily sell them at reduced prices than those of traditional manufacturers (Conn, 2005). In face of the good acceptance by the market, merchants benefit while gaining appropriate recognition and customer loyalty (Caputo, Macedo, \& Nogueira, 2008).

Other perceived advantages when selling private label products include better conditions for the supply of goods, reduction in sales expenses, higher sales volumes, low-budget marketing and advertising, an increase in profit margin, a boost in market share (Caputo et al., 2008), a greater supply goods and services at lower prices (Puerta, 2006), the strengthening of retailer's image and an enhanced bargaining power with suppliers (Parente, 2000). Due to the advantages offered, there is a strong trend among retailers to expand their operations into the private labels (Kotler, 2000).

In addition to an increased use of private labels by retailers, it is also observed that scholars have harbored a huge interest in this subject. In recent years, a large number of studies examined the importance and adoption of the private-labels strategy by retailers, both internationally (Laaksonen \& Reynolds, 1994; Dhar \& Hoch, 1997; Burt, 2000; Chintagunta, Bonfrer, \& Song, 2002; Garretson, Fisher, \& Burton, 2002; Datta, 2003; Kent, 
2003; Miranda \& Joshi, 2003; Davies \& Brito, 2004; Ailawadi \& Keller, 2004; Fearne, Duffy, \& Hornibrook, 2005; Vahie \& Paswan, 2006), and nationally (Neves, Castro, \& Gomes, 2002; Brito \& Brito, 2004; Oliveira, 2005; Paula \& Silva, 2005; Piato, 2006; Piato, Silva, \& Paula, 2007, 2008; Paula, Silva, \& Piato, 2008; Paula, Hingley, Silva, \& Piato, 2008; Paula, Silva, \& Piato, 2013).

From an initial review, it was found that there are no studies available representing the academic production on this subject - private labels and retail - therefore, it is believed that the present research can provide useful input for the market and researchers. In order to communicate academic progress, characteristics of this research and researchers involved, and to create an agenda for future work, this study will perform a bibliometric analysis.

This research deems it important to identify how this subject has been developed and, to this end, it is based on the following research question: what are the characteristics of empirical papers on the subjects of private label and retail, published in national and international journals? To answer that question, the following research objective was established: identify the characteristics of empirical papers on the subjects of private label and retail, published in national and international journals.

The present investigation is justified by the importance of this subject for business and the academic community, as the interest in this subject has widely increased, and also by the absence of bibliometric studies that seek a concerted approach regarding private labels and retail. Through performing bibliometric analysis, this work expects to manage and create knowledge, thus identifying the current status of academic production.

One of the reasons for this study is to present the paths followed by previous works that have addressed the private labels and retail topic. It is possible to identify convergent conclusions and recurrence of topics addressed by previous works. Thus, the importance of investigating the characteristics of these studies is emphasized in order to show the scenario, the form of data collection, the publications which have focused on the issue, the techniques of analysis, the authors who address the issue, among other relevant areas for scientific knowledge.

This study is not limited to the marketing field, since academic research in marketing is related to other fields of expertise and a wide range of phenomena, such as business strategies, market dynamics and consumer society (Hunt, 1976; Jones; Shaw; Mclean, 2010). Besides, scientific research can provide useful knowledge for decision-making and offer a wealth of resources for researchers (Macias-Chapula, 1998).

\section{Theoretical Framework}

\subsection{Private Label and Retail}

A private label is controlled and exclusively sold by a retailer or wholesaler (Raju, Sethuraman, \& Dhar, 1995; Hyman, Kopf, \& Lee, 2008). The private label is managed by distributors and exclusively sold in their stores - either with or without its brand name on the product packaging - and although the factory is in the charge of the production, trademark rights, such as property and usage rights, belong to distributors (Gerstner \& Naik, 1999).

Despite the fact that private labels exist for more than a hundred years (Hoch \& Banerji, 1993; Kumar \& Steenkamp, 2007), their wide use started between the 1970s and 1980s, aiming at making products available to the customer at lower prices than those offered by traditional manufacturers (Kumar \& Steenkamp, 2007). The use of the private label strategy has gained prominence in the world, becoming increasingly important for retail (Braak, Deleersnyder, Geyskens, \& Dekimpe, 2013; Braak, Geyskens, \& Dekimpe, 2014; Miquel-Romero, Caplliure-Giner, \& Adame-Sánchez, 2014).

In Brazil, private labels have emerged in the 1970s, implemented by companies such as Carrefour, Makro and Pão de Açúcar (Peeters, Bisarro, Amaral, \& Bacha, 2006). Initially the products were seen by consumers as low-quality and were usually priced below similar products of leading brands (Peeters et al., 2006; Gonçalves Filho, Sales, \& Gosling, 2013). Gonçalves Filho, Sales and Gosling (2013) agree that private labels reached the Brazilian market in the 1970s, however, they point out that the pioneers were Rede Eldorado, Disco Supermarkets, Rede Bom Preço and Rede Paes Mendonça, multiplying in the following decades. The private label strategy has been strengthened after economic stabilization, mainly arising from Real Plan (Peeters et al., 2006).

The purchase of private label products has increased over the years, mostly among middle and high-class households and, in addition, a stronger demand resulting in a private consumption growth of these products was observed in the 1990s in developed countries, thus it is believed that retail consolidation has helped to impel the sales, and not the economic situation of consumers (Hoyt, 2004). 
Retail is understood as the set of activities that encompass the process of making products and services available and accessible to meet a personal need of the final consumer (Parente, 2000). An increase in industrial competitiveness and the expansion of retail formats have helped enhancing sector growth and the search for the best return on sales, reducing costs and improving margins (Yokoyama, Silva, \& Piato, 2012). In this scenario one can find the link between retail and private labels. Retailers found, through the development of their brands, an opportunity to recover certain lost profits amounts resulting from the increased competition and, in particular situations, due to the stagnation of consumption (Mills, 1995). However, retailers are not only interested in extracting more profits with their own brands, as other advantages are observed, besides, there are also risks and disadvantages when using this strategy.

According to Bambuy, Andrade and Hemzo (2014) the advantages of using a private label strategy outweigh the disadvantages, mainly because the risks taken by retailers can be controlled by the company's managers. Moreover, private label products have the advantage that their managers are also those of the store, therefore they can benefit from the following facts (Hoch, 1996): (i) they are distributed by the best gondola shelving system of the store; (ii) they are present in different product categories throughout the store, which can positively reinforce their image; (iii) managers enjoy more flexibility to make deals at any time; and (iv) managers have the power to determine the price of private brands and also those of their "competitors", i.e., the traditional distributors.

Regarding the disadvantages, there is a risk that the brands can denigrate the company reputation (Spinelli, Giraldi, \& Campomar, 2006). Companies should endeavour to establish the private labels with a strong brand, in addition to invest in advertising and promotions designed to add value to products (Dick, Jain, \& Richardson, 1997). Moreover, when retailers have a high quality image, they find a favorable position, gaining a wider acceptance by customers, thus, in this situation, it is recommended to use the company's own name on the product packaging (Mcgoldrick, 2002). Otherwise, i.e., when the image of the company is not tied to quality, it is not advisable to use the brand name on the label, since the negative opinion on the quality of products hinders sales growth (Garretson et al., 2002; Gracioso \& Najjar, 2003; Unterleider \& Damacena, 2008).

Authors have addressed significant attention to the subject and point out some findings concerning private labels in retail. According to Ashley (1998), the increase in the number of private label products is mainly related to price, since private label products are sold at prices $15 \%$ to $40 \%$ lower than those of traditional suppliers, which tends to gain price-sensitive customers. Bonfrer and Chintagunta (2003) agree and point out that there is an evidence that price-sensitive consumers are the main buyers of private labels.

Private labels are more sensitive to economic fluctuations than brands from traditional suppliers, therefore, they tend to strengthen as the economy faces a period of contraction that reduces the purchasing power of households and, conversely, they suffer sales declines when the economy shows an improvement and the purchasing power of households increases (Quelch \& Harding, 1996). Moreover, according to Huang, Jones, Hahn, and Leone (2010), traditional brands have a larger price elasticity of demand than private labels, so consumers of traditional brands are more sensitive to price changes, when compared with private labels, whether retail is located in upscale districts or modest neighborhoods.

Silverstein and Hirschohn (1994) and Quelch and Harding (1996) concluded that the attractiveness of private labels is directly related to the perception that customers have of products. The higher the quality perceived by consumers the greater the probability of consuming the products and building brand loyalty (Cunha, Marchetti, \& Prado, 2004). Consumers are based on trust to choose products, analyzing indicators such as brand name, price, external appearance, perceived quality, nutritional value and concern about environmental damage (Cunha, Spers, \& Zylbersztajn, 2011; Song, 2012; Gonçalves Filho et al., 2013).

The issue concerning the trend influencing the relationship between retail and private labels must be open to question. Initially, there is a tendency that private labels expand and gain ground for all products categories, such as consumer goods, textiles, home appliances, electronic devices, even expanding its operations to services like financial and insurance (Miquel-Romero et al., 2014). There is also another tendency that may lead retailers to invest in more refined brands, designing and packaging value-added products, consequently approaching leading market brands (Aaker, 1998; Steiner, 2004).

In short, during a long time, private labels did not match the quality level of traditional brands, besides having built a doubtful quality due to their reduced prices (Kumar, 2009; Arenhardt, Battistella, \& Grohmann, 2015). However, in recent years, retailers have increased the quality of their private brands, so these labels went through a transition period, in which it was sought to replace the image of cheap products without quality by quality products with competitive prices (Arenhardt et al., 2015). It is possible to observe companies that are going through this process, 
for example, Qualitá label from Brazilian Pão de Açúcar supermarkets, which directly competes with leading brands by offering similar prices or even above their levels (Silva, Merlo, \& Nagano, 2012).

\section{Methodological Issues}

Dispersion and a large number of available sources of articles has turned the identification of quality scientific papers into a complex task (Tasca, Ensslin, Ensslin, \& Alves, 2010). In this context, particular attention is drawn to the importance of using theoretical approaches and methodologies to map scientific information through methodological strictness (Kobashi \& Santos, 2006). After considering different methods to identify scientific works, such as the Systematic Review (Pittaway, Robertson, Munir, Denyer, \& Neely, 2004) and the Systematic Literature Review (Kitchenham et al., 2009), this study has chosen to apply the Knowledge Development Process - Constructivist (ProKnow-C) (Ensslin, Ensslin, Lacerda, \& Tasca, 2010; Tasca et al., 2010; Bortoluzzi, Ensslin, Ensslin, \& Valmorbida, 2011; Lacerda, Ensslin, \& Ensslin, 2011, 2012; Ensslin, Ensslin, \& Pinto, 2013; Azevedo, Lacerda, Ensslin, \& Jungles, Ensslin, 2013).

This method consists of a series of procedures, initially defining the concept of academic search engine, then following pre-established procedures to reach the data filtering stage and the selection of the relevant Bibliographic Portfolio on the subject (Afonso, Souza, Ensslin, \& Ensslin, 2012). The process consists of four steps (Ensslin, Ensslin, Imlau, \& Chaves, 2014): (i) selection of an article portfolio on the subject of research; (ii) bibliometric analysis of the portfolio; (iii) systemic analysis; and (iv) definition of the question and object of research. Since the goal of this research is to identify the characteristics of empirical papers about private labels and retail, the first two stages of the process were carried out (the selection of a portfolio and bibliometric analysis).

The first step consists in selecting the Bibliographical Portfolio. For this purpose and in first place, the boundaries that limit the scope of the investigation were set: (i) the use of three brazilian electronic repositories - Periódicos Capes, Scielo and Spell; (ii) the search of scientific articles published in peer-reviewed journals; (iii) no temporary cut for national articles and a temporary cut, from 2010 to 2016, for international articles; and (iv) the use of the keywords shown in Chart 1.

\begin{tabular}{|c|c|c|}
\hline \multicolumn{3}{|c|}{ National } \\
\hline Axis 1 & & Axis 2 \\
\hline \multicolumn{3}{|l|}{ "marca própria” OR “marcas próprias" } \\
\hline \multicolumn{3}{|c|}{ International } \\
\hline Axis 1 & & Axis 2 \\
\hline "store brand" OR "store brands" & Retail & \\
\hline "house brand" OR "house brands" & Retailing & \\
\hline "private label brand" OR "private label brands" & Retailer & \\
\hline "own brand" OR "own brands" & Retailers & \\
\hline "home brand" OR "home brands" & & \\
\hline
\end{tabular}

Chart 1. Keywords used to search scientific articles

Source: Elaborated by the authors (2016)

It is observed that the definition of keywords is related to the subjects or fields of knowledge that researchers aim to study, referred here as "axes". The keywords that composed the axes were chosen by researchers after a prior reading of articles focusing on the subject. The searches were conducted on May 2016, by selecting the option "all text fields" and by using the Boolean "AND" between axes, and the Boolean "OR" between terms. The search resulted in a total of 20 bases of international scientific data, among them, 4 major international databases (Elsevier, Web of Science, GALE and Emerald Group Publishing), hosted all the articles.

The survey revealed a total of 267 articles, 79 national and 188 international papers. To ensure relevance and compliance of the articles that were found, these were filtered by the following procedures: (i) an attempt to download the 267 papers found in the search results, however, only 208 papers were obtained, as they were full-free 


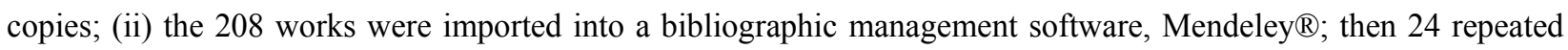
articles were excluded, thus 184 papers remained; (iii) the articles' titles and abstracts were read, excluding those jobs that were misaligned with the search criteria, i.e., to be kept in the Bibliographical Portfolio, the article should: a) address the private label and retail subjects; and b) contribute to the debate on the marketing context.

After performing these procedures, 47 works were chosen to compose the final Bibliographical Portfolio, with 27 international and 20 national papers. In order to check the relevance of the identified articles, the analysis of the number of citations each received is recommended and then one can select the most-cited ones, in other words, it is recommended to classify all articles according to the number of citations received (Tasca et al., 2010; Ensslin et al., 2010; Lacerda et al., 2012; Azevedo et al., 2013). However, the present research decided not to perform such a procedure. The reason behind this decision is that the search and the filters have reported a low number of articles, researchers' readiness to examine all findings and the fact that all articles are recent (between 2010 and 2016).

At the final step, a procedure was performed in order to assess the appropriateness of the keywords initially used. The keywords used by the 47 articles selected were analyzed, to make the goodness-to-fit test. To carry out this task, a word cloud comprising 223 keywords was generated. It was determined that if the keywords used were pointless in relation to the subject, a new search would be performed. Nonetheless, the cloud showed the compliance and representativeness of the primary search, thus the activities were concluded and the portfolio was considered the final version, totaling 47 papers, 20 national and 27 international.

Continuing with the ProKnow-C method, in a second step, a bibliometric analysis was carried out. At that time, a full reading of all papers was performed by the researchers, and information for each article was tabulated, followed by a quantitative evincement of data, that is to say, articles characteristics (Ensslin et al., 2010), this data is shown in the following section.

\section{Presentation and Data Analysis}

In this section, the results obtained with the bibliometric study are presented, from the survey, reading, tabulation and analysis of information of the 47 selected articles. Therefore, the analysis of the results was subdivided into five topics, namely: (i) temporal distribution of the articles; (ii) countries and journals concerned; (iii) authors; (iv) sub-topics, nature and type of research; and (v) data collection techniques and statistical analysis.

\subsection{Temporal Distribution of Articles}

The distribution of the articles over the years is shown in Table 1, where it can be observed that there are temporary interruptions in research production on the subject, since the first study collected was published in 2003 and only in 2006 another study on the subject was published. No publications were identified between 2004 and 2005. The same is true for the year of publication 2010, when articles on the topic could not be found in the researched databases.

Table 1. Distribution of the articles over the years

\begin{tabular}{cccc}
\hline Year of Publication & International & National & Total \\
\hline 2003 & & 1 & 1 \\
2006 & & 1 & 1 \\
2007 & & 1 & 1 \\
2008 & & 2 & 2 \\
2009 & & 1 & 1 \\
2011 & 6 & 2 & 8 \\
2012 & 9 & 4 & 13 \\
2013 & 5 & 1 & 6 \\
2014 & 3 & 5 & 8 \\
2015 & 3 & 1 & 4 \\
2016 & 1 & 1 & 2 \\
\hline Total & 27 & 20 & 47 \\
\hline
\end{tabular}

Source: Elaborated by the authors (2016) 
The year of 2012 showed the highest concentration of articles published on the topic. During that year, a total of 13 articles were published ( $28 \%$ of all the articles that were analyzed). The surveys did not allow to identify the causes of such a high concentration.

\subsection{Countries and Journals Concerned}

Among the 20 studies published in national journals, 19 were conducted in Brazil. The only research conducted abroad and published in a national journal (Revista de Administração de Empresas) was the work by Calvo-Porral, Martínez-Fernández and Juanatey-Boga (2016), researchers from the University of La Coruña, which reported an investigation held in Spain.

Spain congregates the largest number of research published in international journals. Although this study did not specifically investigate the reasons for this finding, it is believed that the interest of researchers is related to the fact that private labels are gaining more space in the Spanish retail. After the economic recession of 2008, private labels held about $40 \%$ of total supermarket sales in that country. (Sellers-Rubio \& Nicolau-Gonzalbez, 2015).

Table 2 shows the scenario in which the research was conducted. One can observe in that table that the total scenarios in which the international research was developed is 29 . This was due to the that some researches were performed in more than one country.

Table 2. Scenarios in which researches were carried out

\begin{tabular}{lccc}
\hline Research scenario & International & National & Total \\
\hline Brazil & 1 & 19 & 20 \\
Spain & 12 & 1 & 13 \\
United States & 4 & & 4 \\
France & 3 & & 3 \\
South Africa & 1 & & 1 \\
Germany & 1 & & 1 \\
Australia & 1 & & 1 \\
Chile & 1 & & 1 \\
United Kingdom & 1 & & 1 \\
Malaysia & 1 & & 1 \\
Norway & 1 & & 1 \\
Not unveiled & 2 & & 2 \\
\hline Total & 29 & 20 & 47 \\
\hline
\end{tabular}

Source: Elaborated by the authors (2016)

Despite the high concentration of researches carried out in Spain and, of course, in Europe, studies conducted have been identified in 11 countries belonging to five different continents. This suggests that the subject has been comprehensively studied and in different scenarios and contexts, which may allow, in future research, a comparison between data obtained in different cultures.

National papers are distributed in 19 different journals. Only the journal "Revista de Administração Mackenzie" published more than one article on the subject. Periodicals are associated with various areas of business administration, thus are not only restricted to the Marketing field, since they range from Business and Corporate Entrepreneurship to Strategic and Production Management. This heterogeneity was identified in international articles. In this case, three newspapers (two British and one American) concentrated 13 of the 27 studies analyzed, all belonging to the academic field of Business, Trade and Marketing, according to Table 3.

Table 3 displays the name of the journals with two or more published articles, and, in total, 39 journals were identified (15 international and 19 national). 
Table 3. Journals in which the articles were published

\begin{tabular}{|c|c|c|c|}
\hline Journal & International & National & Total \\
\hline International Journal of Retail \& Distribution Management & 5 & & 5 \\
\hline Journal of Product \& Brand Management & 5 & & 5 \\
\hline Journal of Business Research & 3 & & 3 \\
\hline British Food Journal & 2 & & 2 \\
\hline Journal of Retailing & 2 & & 2 \\
\hline Revista de Administração Mackenzie & & 2 & 2 \\
\hline
\end{tabular}

Source: Elaborated by the authors (2016)

The International Journal of Retail \& Distribution Management, which is classified as Qualis A1 according to the Brazilian CAPES System, published researches carried out in Spain and France, while its British counterpart, the Journal of Product \& Brand Management, classified as Qualis A2, presented studies from the United States, South Africa and Germany. Researches conducted in Chile, Spain and Norway were among the 03 papers published in the American Journal of Business Research.

\subsection{Authors}

The largest number of works were produced by researchers associated with the University of La Coruña Calvo-Porral, Martínez-Fernández and Juanatey-Boga. The authors jointly sign articles and also with Professor Jean-Pierre Lévy-Mangin, from the Université du Québec, another researcher with an outstanding academic production. Studies on private label and retail conducted by those experts always use supermarkets as a research environment, ranging the sub-topics to be explored (consumer behavior, consumer perception, purchase intention and loyalty). The assistant professor at the University of Lille, Mbaye Fall Diallo, is also among the authors with a remarkable production among the those signing the international articles analyzed.

Figure 1 shows the list with the main authors identified.

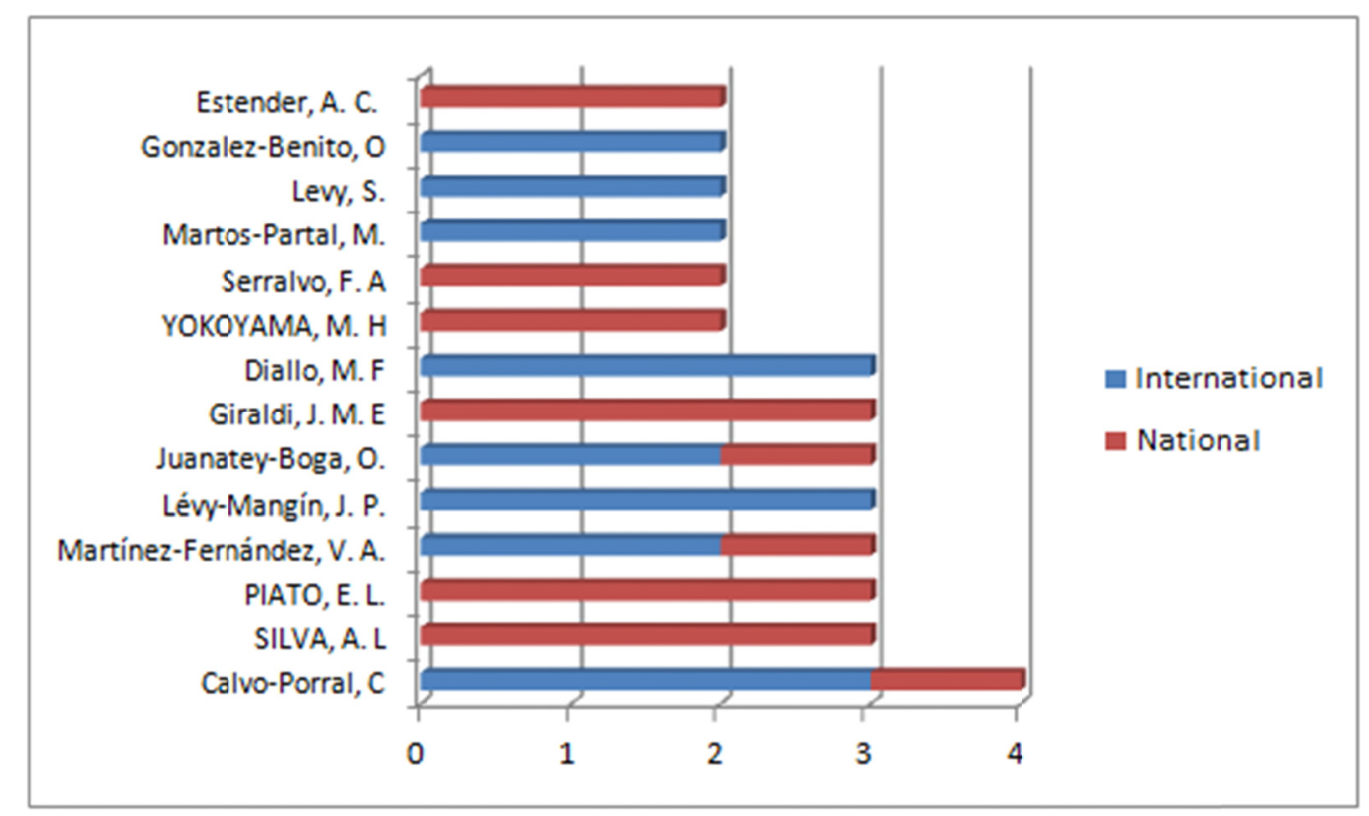

Figure 1. Main authors on the subject

Source: Elaborated by the authors (2016) 
Among the authors with the highest number of papers published in national journals are Professors Éderson Luiz Piato and Andrea Lago da Silva, both from the Federal University of São Carlos. Works performed by these authors broaden the perspective of other actors involved in the supply chain/production, in addition to retailers.

\subsection{Sub-topic, Nature and Type of Research}

It was noticed a greater alignment between sub-topics in the international academic works, where five axes guided the agenda (loyalty, purchase intention, consumer behavior, consumer perception and product positioning). The scenario is different in the national context. In this case, the "consumer perception" and "product positioning" issues remarkably stood out among the sub-topics.

One must highlight that three sub-topics only appeared in national journals, two of them in a more intense manner ("product development" and "relationship between retailers and manufacturers"), and half of these are related to the works by the aforementioned authors, Professors Piato and Silva, who furthered their investigations on the chain supply that reaches beyond the retailer.

The national academicc production, unlike the international, did not present the "consumer behavior" issue as a sub-topic to be referenced. This may reflect the preponderance of the characteristics of qualitative approaches, which are largely based on consumer or manager opinion surveys, so present in national polls.

Table 4. Sub-topics addressed in the articles

\begin{tabular}{lccc}
\hline \multicolumn{1}{c}{ Sub-topic } & International & National & Total \\
\hline Consumer Perception & 4 & 7 & 11 \\
Product Positioning & 4 & 4 & 8 \\
Purchase Intention & 6 & 1 & 7 \\
Loyalty & 6 & 1 & 7 \\
Consumer Behavior & 5 & & 5 \\
Products Development & & 3 & 3 \\
Relationship between retailers and & & 3 & 3 \\
manufacturers & & 1 & 1 \\
Risks and Rewards & 1 & & 1 \\
Supply Chain & 1 & & 1 \\
Umbrella Branding & 27 & 20 & 47 \\
\hline Total & &
\end{tabular}

Source: Elaborated by the authors (2016)

The international studies were mainly quantitative, and the qualitative approach, in some cases, was present as a tool for pre-analysis or pre-qualification of data collection instruments and variables that should be investigated.

Table 5. Nature of research

\begin{tabular}{lccc}
\hline Nature of Research & International & National & Total \\
\hline Quali-Quanti & 3 & 2 & 5 \\
Qualitative & & 9 & 9 \\
Quantitative & 24 & 9 & 33 \\
\hline Total & 27 & 20 & 47 \\
\hline
\end{tabular}

Source: Elaborated by the authors (2016) 
In the same context, national surveys, as shown in Table 6 , are mostly exploratory and descriptive, considering the following research classification: descriptive, exploratory, pre-experimental, quasi-experimental and experimental. International studies, in turn, are mainly concentrated in the pre-experimental category, i.e., studies examining the correlation between variables.

Table 6. Type of research

\begin{tabular}{lccc}
\hline \multicolumn{1}{c}{ Type of Research } & International & National & Total \\
\hline Descriptive & 2 & 6 & 6 \\
Experimental & & 7 & 2 \\
Exploratory & & 1 & 1 \\
Exploratory (Multi-case) & & 1 & 1 \\
Exploratory-Descriptive & 23 & 5 & 28 \\
Pre-experimental & 2 & & 2 \\
Quasi-experimental & 27 & 20 & 47 \\
\hline Total & &
\end{tabular}

Source: Elaborated by the authors (2016)

This is a significant difference of approach between the national academic environment and the way international researchers carry out their works. This difference affects, among other things, the low inferential ability of national studies, the difficulties these works show to point out using generalizations, or even contribute to managerial implications in a more clear and effective manner. Within the "exploratory" position adopted by national researchers, studies or multi-cases are abundant and the point of arrival indicates, to a great extent, just a new starting point for future investigations.

The low number of quasi-experimental and experimental researches, even considering the international research, is an issue at which one should look carefully, as it may be related to difficulties in performing such studies that require control of variables and control groups.

\subsection{Data Collection Technique and Statistical Analyses}

As can be seen in Table 7, there is a predominance of survey/questionnaire application, both in national and international studies, and in the particular case of international studies, this type of data collection was mostly used in pre-experimental studies (it was used in 16 studies, of a total of 23). In the five national pre-experimental studies, data collection was carried out by using this tool.

Table 7. Data collection techniques used in the articles

\begin{tabular}{lccc}
\hline Strategy/Data Collection Technique & International & National & Total \\
\hline Document Analysis & 6 & 1 & 6 \\
Bibliography and Interviews & & 2 & 2 \\
Interview & & 2 & 2 \\
Document Analysis, Bibliography and Interviews & & 3 & 3 \\
Observation & 18 & 2 & 2 \\
Survey/questionnaire & 3 & 10 & 28 \\
Interviews and Survey/questionnaire & 27 & 20 & 3 \\
\hline Total & & & 47 \\
\hline
\end{tabular}

Source: Elaborated by the authors (2016) 
It is also worth highlighting that interviews, whether associated with other techniques or used alone, were only applied in national surveys. When analyzing the statistical methods used, one can notice that in international studies, as highlighted in Figure 2, there is a predominance of the structural equation model, while national studies do not perform statistical treatment or when they do, the descriptive approach is mainly applied. This may indicate a trend of low methodological strictness to process data in national studies.

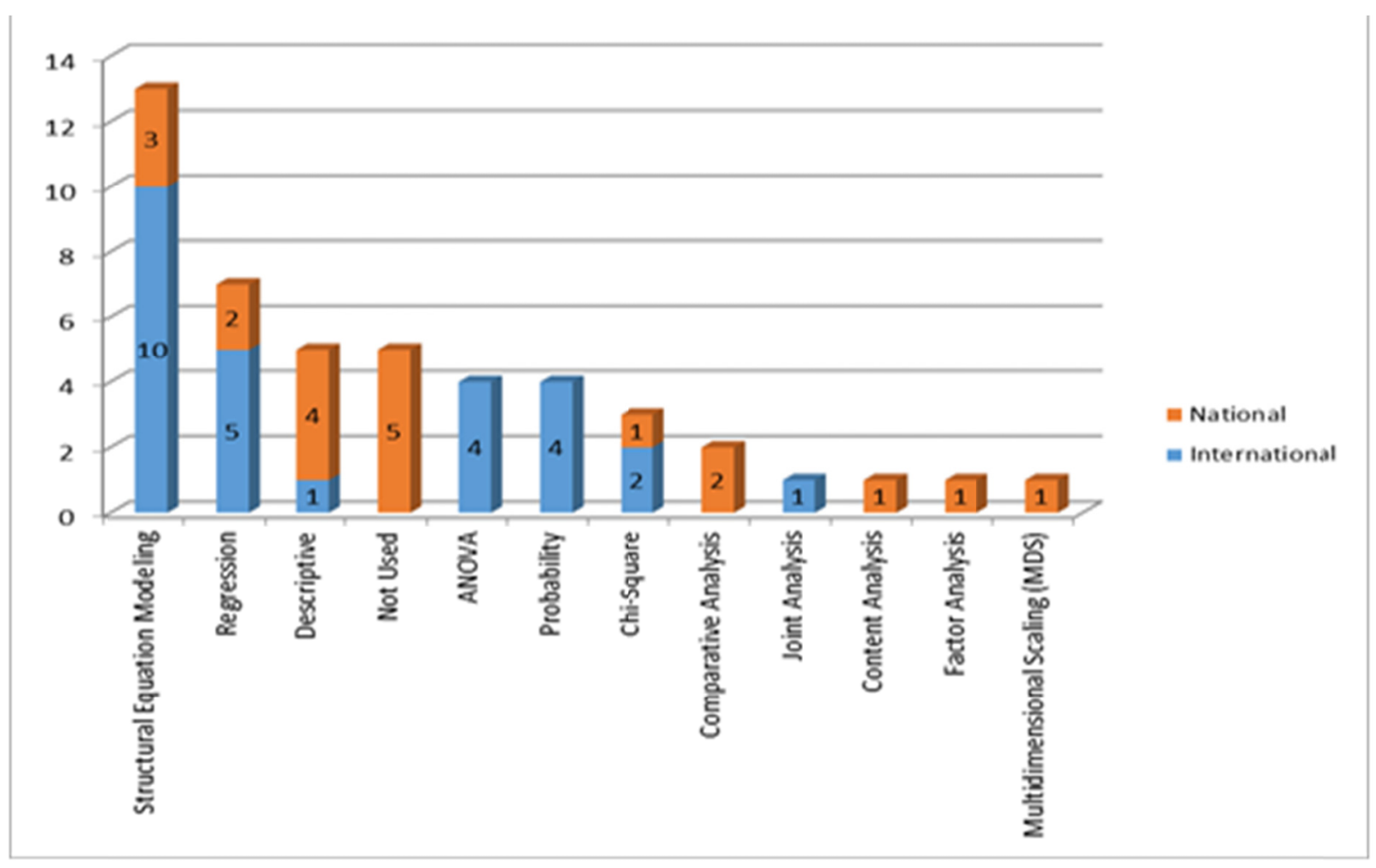

Figure 2. Statistical analysis performed

Source: Elaborated by the authors (2016)

However, when analyzing the five works that did not use statistical analysis, it was noticed that three of these are exploratory studies. According to Gil (1999), this type of research aims at enhancing ideas or investigating intuitions, which could justify the absence of statistical analysis.

\section{Concluding Remarks}

The present research aimed at identifying the characteristics of empirical papers on private labels and retail subjects, published in national (brazilian) and international journals. The study allowed the researchers to assess the conditions of academic production on the subject, and thus apprehend the main topics that are currently being addressed. The study achieved its initial objective, whereas by applying the ProKnow-C, it was able to identify the research profile concerning that subject. Nevertheless, the absence of a similar work on this topic made it impossible to compare the present research with other studies.

There is a low number of studies on this subject. It was expected a higher number of national paper works, since a temporal cut was not established. It was also identified that the research published in national journals are scientific investigations predominantly conducted in Brazil. This finding reveals that national journals are not sought out to publish works conducted in other countries. Regarding the authors of the articles, there were no relationships between national and international authors, i.e., there was no publications jointly signed by Brazilian authors and foreign authors. From the theoretical point of view, the works become similar when they demonstrate that the private labels occupy a place in retailing, for both times of turbulence and economic tranquility. However, Brazilian and international studies differ mainly by the methodology used. 
It was possible to identify a very different profile between national and international researches. Concerning this issue, national studies focused on identifying the consumer perception in relation to private label products and how the products positioning interferes with their acceptance. In international surveys, regularization is mainly observed on the variables that interfere with the consumers purchase intention and loyalty towards those products and retailers. In addition, three sub-topics were addressed in national surveys but were not in international researches: product development, relationship between manufacturers and retailers and the risks and rewards of using private labels. It is believed that the differences between the sub-topics addressed are due to the maturity os scientific research, since the national surveys only recently began to address the issue, in comparison with the international research teams.

There is a predominance of quantitative studies on the part of international research and, in relation to national surveys, these were carried out both from the quantitative as well as qualitative perspectives. In order to collect data, both international and national surveys used the survey/questionnaires techniques and, to a lesser extent, national surveys have chosen to conduct interviews. International surveys have chosen to conduct experiments (pre or quasi), while national surveys limited their scope and conducted exploratory and descriptive researches.

Like any scientific research, this study has some limitations. It is noteworthy that this research has been limited to scientific articles published in journals and available in the databases consulted. Another limitation refers to the interpretation of those papers and the tabulation of their characteristics, that is to say, the qualitative analysis. Although researchers determined methodological criteria that should be followed, the subjectivity of each individual might interfere with the interpretation of the articles.

Additionally, other analyses could have been carried out to verify the Brazilian Qualis Capes classification of the journals that published on the subject apart from their primary area of expertise, thus one could outline their profile. Sociograms demonstrate how the authors interact, if they work in isolation or whether if inter-relationships between authors and institutions exist. A broader analysis regarding the academic production in the marketing field would allow a comparison between the whole and the specific production on retail and private label topics. This comparison would check if the subject of this research is a hot topic or not. Besides, a comparative table of the number of authors publications versus the most cited nationwide may provide a better understanding of the scenario. Internationally, such analysis would not be interesting, since the period taken into account for the investigation is very recent, therefore, more time would be needed so that the articles can be cited by other works.

\section{References}

Aaker, D. A. (1998). Marcas - brand equity: Gerenciando o valor da marca. São Paulo: Negócio Editora.

Afonso, M. H. F., Souza, J. V., Ensslin, S. R., \& Ensslin, L. (2011). Como construir conhecimento sobre o tema de pesquisa? Aplicação do processo Proknow-C na busca de literatura sobre avaliação do desenvolvimento sustentável. Revista de Gestão Social e Ambiental, 5(2), 47-62. Retrieved from https://goo.g1/7u0B0o

Ailawadi, K. L., \& Keller, K. L. (2004). Understanding retail branding: Conceptual insights and research priorities. Journal of Retailing, 80(4), 331-342. http://dx.doi.org/10.1016/j.jretai.2004.10.008

Arenhardt, D. L., Battistella, L. F., \& Grohmann, M. Z. (2015). As estratégias dos fornecedores de marcas próprias e o seu poder de negociação frente aos varejistas: Um estudo com pequenos fabricantes. Revista de Empreendedorismo e Gestão de Pequenas Empresas, 4(2), 183-218. Retrieved from http://goo.gl/u6ArRN

Ashley, S. R. (1998). How to effectively compete against private-label brands. Journal of Advertising Research, 38(1), 75-82.

Azevedo, R. C., Lacerda, R. T. O., Ensslin, L., Jungles, A. E., \& Ensslin, S. R. (2013). Performance measurement to aid decision making in the budgeting process for apartment-building construction: case study using MCDA-C. Journal of Construction Engineering and Management, 139(2), 225-235. http://dx.doi.org/10.1061/(ASCE)CO.1943-7862.0000587

Bambuy, L. R., Andrade, J., \& Hemzo, M. A. (2014). A captura de valor das marcas líderes pelas marcas próprias. Um estudo exploratório sobre semelhança de embalagens. Revista Brasileira de Marketing, 13(6), 64-79. http://dx.doi.org/10.5585/remark.v13i6.2803

Batra, R., \& Sinha, I. (2000). Consumer-level factors moderating the success of private label brands. Journal of Retailing, 76(2), 175-191. http://dx.doi.org/10.1016/S0022-4359(00)00027-0

Bonfrer, A., \& Chintagunta, P. K. (2004). Store brands: Who buys them and what happens to retail prices when they are introduced? Review of Industrial Organization, 24(2), 195-218. http://dx.doi.org/10.1023/B:REIO.0000033352.19694.4a 
Bortoluzzi, S. C., Ensslin, S. R., Ensslin, L., \& Valmorbida, S. M. I. (2011). A avaliação de desempenho em redes de pequenas e médias empresas: Estado da arte para as delimitações postas pelo pesquisador. Revista Eletrônica de Estratégia \& Negócios, 4(2), 202-222. Retrieved from http://goo.gl/Qs7d38

Braak, A. T., Deleersnyder, B., Geyskens, I., \& Dekimpe, M. G. (2013). Does private- label production by national-brand manufacturers create discounter goodwill? International Journal of Research in Marketing, 30(4), 343-357. http://dx.doi.org/10.1016/j.ijresmar.2013.03.006

Braak, A., Geyskens, I., \& Dekimpe, M. G. (2014). Taking private labels upmarket: empirical generalizations on category drivers of premium private label introductions. Journal of Retailing, 90(2), 125-140. http://dx.doi.org/10.1016/j.jretai.2014.01.003

Brito, E. P. Z., \& Brito, L. A. L. (2004). Private label supply chains: A model for competitiveness. Euroma Conference, FRA, 11, 1-10. Retrieved from https://goo.gl/7AVaw1

Brookes, B. C. (1969). Bradford's law and the bibliography of science. Nature, 224(1), 953-956. http://dx.doi.org/10.1038/224953a0

Burt, S. (2000). The strategic role of retail brands in British grocery retailing. European Journal of Marketing, 34(8), 875-890. http://dx.doi.org/10.1108/03090560010331351

Caputo, É. S., Macedo, M. A. S., \& Nogueira, H. G. P. (2008). Avaliação de marcas: Uma aplicação ao caso Bombril. Revista de Administração de Empresas-RAE eletrônica, 7(2), 1-25. http://dx.doi.org/10.1590/S1676-56482008000200005

Chintagunta, P., Bonfrer, A., \& Song, I. (2002). Investigating the effects of store-brand introduction on retailer demand and pricing behavior. Management Science, 48(10), 1242-1267. http://dx.doi.org/10.1287/mnsc.48.10.1242.274

Conn, C. (2005). Innovation in private-label branding. Design Management Review, 16(2), 55-72. http://dx.doi.org/10.1111/j.1948-7169.2005.tb00194.x

Cunha, C. F., Spers, E. E., \& Zylbersztajn, D. (2011). Percepção sobre atributos de sustentabilidade em um varejo supermercadista. Revista de Administração de Empresas-RAE, 51(6), 542-552. http://dx.doi.org/10.1590/S0034-75902011000600004

Cunha, F., Marchetti, R., \& Prado P. (2004). Lealdade do consumidor às marcas próprias de produtos alimentícios comercializados em supermercados. Encontro de Marketing da Associação Nacional de Programas de Pós-Graduação, BR, 28, 1-16. Retrieved from http://repositorio.furg.br/handle/1/5488

Datta P. R. (2003). The determinants of brand loyalty. Journal of American Academy of Business, 3(1/2), 138-144. Retrieved from http://migre.me/uzqQt

Davies, G., \& Brito, E. (2004). Price and quality competition between brands and own brands: A value systems perspective. European Journal of Marketing, 38(1/2), 30-55. http://dx.doi.org/10.1108/03090560410511113

Dhar, S. K., \& Hoch, S. J. (1997). Why store brand penetration varies by retailer. Marketing Science, 16(3), 208-227. http://dx.doi.org/10.1287/mksc.16.3.208

Dick, A., Jain, A., \& Richardson, P. (1997). How consumers evaluate store brands. Pricing Strategy \& Practice, 5(1), 18-24. http://dx.doi.org/10.1108/10610429610119405

Dunne, P., \& Lusch, R. F. (1999). Retailing. Boston: Dryden Press.

Ensslin, L., Ensslin, S. R., \& Pinto, H. M. (2013). Processo de investigação e análise bibliométrica: Avaliação da qualidade dos serviços bancários. Revista de Administração Contemporânea, 17(3), 325-349. http://dx.doi.org/10.1590/S1415-65552013000300005

Ensslin, L., Ensslin, S. R., Lacerda, R. T. O., \& Tasca, J. E. (2010). ProKnow-C, knowledge development process constructivist. Processo técnico com patente de registro pendente junto ao INPI.

Ensslin, S. R., Ensslin, L., Imlau, J. M., \& Chaves, L. C. (2014). Processo de mapeamento das publicações científicas de um tema: Portfólio bibliográfico e análise bibliométrica sobre avaliação de desempenho de cooperativas de produção agropecuária. Revista de Economia e Sociologia Rural, 52(3), 587-608. http://dx.doi.org/10.1590/S0103-20032014000300010 
Fearne, A., Duffy, R., \& Hornibrook, S. (2005). Justice in UK supermarket buyer-supplier relationships: an empirical analysis. International Journal of Retail and Distribution Management, 33(8), 570-582. http://dx.doi.org/10.1108/09590550510608377

Garretson, J. A., Fisher, D., \& Burton, S. (2002). Antecedents of private label attitude and national brand promotion attitude: Similarities and diferences. Journal of Retailing, 78(2), 91-99. http://dx.doi.org/10.1016/S0022-4359(02)00071-4

Gerstner, E., \& Naik, P. (1999). Branding and private label strategies. Florida: CRC Press.

Gil, A. C. (1999). Métodos e técnicas de pesquisa social. São Paulo: Atlas.

Gracioso, F., \& Najjar, E. R. (2003). Desenvolvimento de marcas próprias no Brasil: A experiência do Grupo Pão de Açúcar. Revista ESPM, 10(1), 105-113. Retrieved from http://goo.gl/UiGv3Z

Hoch, S. J. (1996). How should national brands think about private labels? Sloan Management Review, 37(2), 89-102. Retrieved from http://goo.gl/5jsBC5

Hoch, S. J., \& Banerji, S. (1993). When do private labels succeed? Sloan Management Review, 34(4), 57-67. Retrieved from http://goo.gl/5jsBC5

Hoyt, C. (2004). Retailers push private label. Beverage Industry, 95(6), 20-35.

Huang, M. H., Jones, E., Hahn, D. E., \& Leone, R. P. (2010). Assessing price elasticity for private labels and national brands by store locations. Journal of Revenue and Pricing Management, 11(2), 175-190. http://dx.doi.org/10.1057/rpm.2010.32

Hunt, S. D. (1976). The nature and scope of marketing. Journal of Marketing, 40(3), 17-28. Retrieved from http://goo.gl/tv4RL3

Hyman, M. R., Kopf, D. A., \& Lee, D. (2010). Review of literature- future research suggestions: Private label brands: benefits, success factors and future research. Journal of Brand Management, 17(5), 368-389. http://dx.doi.org/10.1057/bm.2009.33

Jones, D. G. B., Shaw E. H., \& Mclean, P. A. (2010). The modern schools of marketing thought. Los Angeles: Sage.

Kent, T. (2003). 2D23D: Management and design perspectives on retail branding. International Journal of Retail \& Distribution Management, 31(3), 131-142. http://dx.doi.org/10.1108/09590550310465503

Kitchenham, B., Brereton, O. P., Budgen, D., Turner, M., Bailey, \& Linkman, S. (2009). Systematic literature reviews in software engineering: A systematic literature review. Information and Software Technology, 51(1), 7-15. http://dx.doi.org/10.1016/j.infsof.2008.09.009

Kobashi, Y., \& Santos, R. N. M. (2006). Institucionalização da pesquisa científica no Brasil: Cartografia temática e de redes sociais por meio de técnicas bibliométricas. TransInformação, 18(1), 27-36. Retrieved from http://goo.gl/ks9cwS

Kotler, P. (2000). Administração de marketing. São Paulo: Prentice Hall.

Kumar, A. (2009). Marketing management. New Delhi: Vikas Publishing.

Kumar, N., \& Steenkamp, J. E. M. (2007). Private label strategy: How to meet the store brand challenge. Boston: Harvard Business School Press.

Laaksonen, H., \& Reynolds, J. (1994). Own brands in food retailing across Europe. Journal of Brand Management, 2(1), 37-46. http://dx.doi.org/10.1057/bm.1994.30

Lacerda, R. T. O., Ensslin, L., \& Ensslin, S. R. (2011). Contribuições à gestão estratégica de organizações quando analisados na visão de seu desempenho. GESTÃO.Org - Revista Eletrônica de Gestão Organizacional, 9(2), 327-358. Retrieved from http://goo.gl/fLDxCC

Lacerda, R. T. O., Ensslin, L., \& Ensslin, S. R. (2012). Uma análise bibliométrica da literatura sobre estratégia e avaliação de desempenho. Gestão \& Produção, 19(1), 59-78. http://dx.doi.org/10.1590/S0104-530X2012000100005

Macias-Chapula, C. A. (1998). O papel da informetria e da cienciometria e sua perspectiva nacional e internacional. Ciência da Informação, 27(2), 134-140. http://dx.doi.org/10.18225/ci.inf..v27i2.794.g825

Mcgoldrick, P. (2002). Retail marketing. London: McGraw-Hill. 
Mills, D. E. (1995). Why Retailers Sell Private Labels. Journal of Economics and Management Strategy, 4(3), 509-528. http://dx.doi.org/10.1111/j.1430-9134.1995.00509.x

Miquel-Romero, M. J., Caplliure-Giner, E. M., \& Adame-Sánchez, C. (2014). Relationship marketing management: Its importance in private label extension. Journal of Business Research, 67(5), 667-672. http://dx.doi.org/10.1016/j.jbusres.2013.11.025

Miranda, M. J., \& Joshi, M. (2003). Australian retailers need to engage with private labels to achieve competitive difference. Asia Pacific Journal of Marketing and Logistics, 15(3), 34-47. http://dx.doi.org/10.1108/13555850310764999

Neves, M. F., Castro, L. T., \& Gomes, C. C. M. P. (2002b). Lançar produtos via marcas próprias: As relações entre os produtores e os retalhistas. Marketeer, 7(76), 78-81.

Oliveira, R. N. A. (2005). Marca própria. Rio de Janeiro: Brasport.

Parente, J. (2000). Varejo no Brasil: Gestão e estratégia. São Paulo: Atlas.

Paula, A. F., \& Silva, A. L. (2005). Private labels and relationship on the marketing channel: A case study in grocery industry. Annual Conference of Production and Operations Management Society, USA, 16, 1-15.

Paula, A. F., Silva, A. L., \& Piato, E. L. (2013). Estratégia de marcas próprias no varejo supermercadista: Um estudo comparativo entre Brasil e Inglaterra. Produção, $23(1), \quad$ 66-79. http://dx.doi.org/10.1590/S0103-65132012005000025.

Paula, V. A. F., Silva, A. L., \& Piato, É. L. (2008). The management of private labels in food retailers: A multi-case study in England with food retailers and private label suppliers. International Conference on Management in Agrifood Chains and Networks, NLD, 8, 1-14. Retrieved from http://ofi.openfields.org.uk/2.10020253

Paula, V. F., Hingley, M., Silva, A. L., \& Piato, E. (2008). Product development and Operations management in UK supermarket private labels. International Annual Euroma Conference, NLD, 15, 1-14. Retrieved from http://eprints.lincoln.ac.uk/4270/

Peeters, T. H., Bisarro, M. L. B., Amaral, F. S., \& Bacha, M. L. (2006). Estratégias de marca própria refletida na imagem percebida pelos compradores de super/hipermercados. Jovens Pesquisadores, 3(1). Retrieved from http://goo.gl/VFMpdM

Piato, E. L. (2006). Estratégia de marcas próprias: Estudo multicaso no atacado brasileiro (Dissertação de Mestrado). Universidade Federal de São Carlos. Retrieved from https://goo.gl/jNI0FN

Piato, É. L., Silva, A. L., \& Paula V. A. F. (2007). Vantagens e desvantagens da estratégia de marcas próprias no atacado: Análise comparativa entre revisão da literatura e contexto atacadista. Encontro Anual da Associação Nacional de Pós-Graduação e Pesquisa em Administração, BR, 31, 1-15. Retrieved from http://goo.gl/qAWWkZ

Piato, É. L., Silva, A. L., \& Paula V. A. F. (2008). Identificando os elementos da estratégia de marketing: O caso da "estratégia" de marcas próprias do atacado. Encontro de marketing da Associação Nacional de Pós-Graduação e Pesquisa em Administração, BR, 3, 1-16. Retrieved from http://goo.gl/UxtN4I

Pittaway, L., Robertson, M., Munir, K., Denyer, D., \& Neely, A. (2004). Networking and innovation: A systematic review of the evidence. International Journal of Management Reviews, 5/6(3/4), 137-168. http://dx.doi.org/10.1111/j.1460-8545.2004.00101.x

Puerta, R. (2006). Mercado em expansão: Pesquisa marca própria. Revista Distribuição, 14(158), 38-40.

Quelch, J. A., \& Harding, D. (1996). Brands versus Private Labels: Fighting to win. Harvard Business Review, 74(1), 99-109. Retrieved from https://goo.gl/2TdIC1

Raju, J. S., Sethuraman, R., \& Dhar, S. K. (1995). The introduction and performance of store brands. Management Science, 41(6), 957-978. http://dx.doi.org/10.1287/mnsc.41.6.957

Silva, L. A., Merlo, E. M., \& Nagano, M. S. (2012). Uma análise dos principais elementos influenciadores da tomada de decisão de compra de produtos de marca própria de supermercados. Revista eletrônica de Administração, 71(1), 97-129. http://dx.doi.org/10.1590/S1413-23112012000100004

Silverstein, M. J., \& Hirschohn, L. (1994). Exposing the five myths of private label brands. Brandweek, 35(25), 17-18. 
Song, W. (2012). Possible causes inhibiting the purchase of Chinese grocery own brands: A preliminary study. Journal of Business Economics and Management, 13(2), 207-222. http://dx.doi.org/10.3846/16111699.2011.620160

Spinelli, P. B., Giraldi, J. M. E., \& Campomar, M. C. (2006). Retail private label strategies. Revista de Administração Mackenzie, 7(4), 121-141. Retrieved from http://goo.gl/BD6dJL

Steiner, R. L. (2004). The nature and benefits of national brand/private label competition. Review of Industrial Organization, 24(2), 105-127. Retrieved from http://goo.gl/Gmc3bw

Tasca, J. E., Ensslin, L., Ensslin, S. R., \& Alves, M. B. M. (2010). An approach for selecting a theoretical framework for the evaluation of training programs. Journal of European Industrial Training, 34(7), 631-655. http://dx.doi.org/10.1108/03090591011070761

Unterleider, J. A. A., \& Damacena, C. (2006). Estratégia de desenvolvimento de marcas próprias por supermercados no brasil. Revista de Administração Mackenzie, 7(3), 63-89. Retrieved from http://goo.gl/Z4NauP

Vahie, A., \& Paswan, A. (2006). Private label brand image: Its relationship with store image and national brand. International Journal of Retail \& Distribution Management, 34(1), 67-84. http://dx.doi.org/10.1108/09590550610642828

Yokoyama, M. H., Silva, A. L., \& Piato, E. L. (2012). Desenvolvimento de marcas próprias: Estudo comparativo entre o varejo e fornecedores da indústria alimentícia. Gestão da Produção, 19(3), 543-556. http://dx.doi.org/10.1590/S0104-530X2012000300008 